\title{
OCCULT POWER AND AFRICA'S SOCIO-ECONOMIC PROBLEMS
}

\section{Aloysius Obiwulu}

\begin{abstract}
It is known to Africans and the international community that Africa is a poor continent, though she is very rich in mineral and human resources. Her basic problems as a continent include: bad leadership, corrupt and selfish politicians, mismanagement of resources, high degree of illiteracy etc. These have led the continent into various socio-economic problems including poverty and war. My research has proved that in Africa, especially in the sub-Saharan part, many people believe in the existence of occult powers and this belief affects their behaviours: the way they do business, their attitude to one another, their political and social life. Such occult powers include: witchcraft, sorcery, possession of extra ordinary power, divination and ability to foretell the future, conjuring the dead, mermaid spirits, jujus (gods and goddesses), ability to control various spirits, etc. Academics in various fields, successful business men and women, renowned politicians, legal practitioners accept that occult phenomena influence the way they lead their lives and carry on with their businesses and professions. This paper investigates in a critical and coherent manner whether Africans can make use of occult powers to solve their problems. For example, could corrupt politicians and dictators be removed from office by the use of occult powers? What use could be made of the so-called occult powers of witchcraft, necromancy, jujus etc. in solving Africa's problems?
\end{abstract}

\section{Introduction}

In Africa, as in some other continents, the belief in the powers and influence of the occult is widespread. In the socio-political sphere as well as among the academia and religious professionals in Africa this belief plays a prominent role. The media support it and report almost weekly on the "use" of this power. The pages of Newspapers and Newsmagazines are replete with such records and reports that are difficult to believe. People claim to have occult powers which 
they can use for their own "good" and which they can also use to help those who are ready to pay for their services.

The occult powers include the ability to change from a human being into an animal, the power to call up the spirit of a dead man/woman, ability to diagnose and cure illnesses through casting of pins (that are said to be responsible for the ailment), witchcraft powers, ability to cause and stop road accidents, possession of miraculous powers of healing, clairvoyance and bilocation, etc.

This paper, which is the fruit of a prolonged research into the existence and influence of paranormal and occult powers, argues that many people believe in occult powers. It asks why people who believe in the existence of such powers and those who claim to have them, have not started using them to positively influence the socioeconomic/political condition of their country and continent.

\section{Occult Power: Meaning and Explanation}

The word "occult" refers to what is hidden as opposed to what is made public or open. It is not what everybody knows. It is revealed or given only to a few. According to Chambers $20^{\text {th }}$ Century Dictionary, occult is what is, "secret, esoteric, unknown, not discovered without test or experiment; beyond the range of sense, transcending the bounds of natural knowledge; mysterious, magical, supernatural.",

What is occult is what is mysterious, invisible and occultism is "the doctrine or study of things hidden or mysterious." 2 There are several powers which some people claim to have. These kinds of power are restricted only to such people, to the initiated or to all the members of a given group that possess them. Power that is regarded as secret or occult is not given to everybody. Witches, wizards, traditional medicine men/women, members of secret cults/societies, clairyovants, people with miraculous powers are among those, who, in Africa are believed to have occult powers with which they carry out different assignments, often to their own advantage or to the advantage of the members of their group or their friends.

Occult powers are not provable by scientific experiments and experience. For Oguejiofor, occult powers should be understood as:

...special mysterious powers granted to individuals and groups of individuals, either as specialist or by heredity, or 
by initiation into occult groups. Occult powers can also be acquired by the application of special charms made by special experts. $^{3}$

Belief in occult powers are different from religious belief, though they many seem to be related. This Oguejiofor also pointed out. ${ }^{4}$ There are instances where some people take occultism to be a form of religion. But it is not really a religion, since membership to such a group is restricted and the doctrines are kept secret and the adherents often take oath of secrecy. Thus, the power of the divine to intervene in normal human affairs which is regarded as miracle is excluded from our understanding of occult power.

In order to explain miracles, theologians usually make a distinction between God's providentia ordinaria and God's providentia extraordinaria. It is the latter that is generally regarded and identified as miracles....

In a simple language, miracles in general are "events which are the product of natural causes but whose context is such as to suggest a special divine intention with regard to their occurrence." ${ }^{\prime 6}$ Miracle belongs to the realm of religion and not to the domain of occultism.

Many people in Africa believe in the existence of occult powers. They believe that with such powers people could perform or do what is normally and naturally beyond the ability of human beings. For example, human beings naturally do not turn into rats and other animals. But some believe this is possible by the possession of a mystical power, power which witches and wizards are said to possess. For the purpose of this article, occult powers exclude all those powers which could be explained by today's science. Occult powers do not include the medicinal curatives powers of plants and herbs, which could be explained by pharmacy and pharmacology; nor do they include occurrences which are explicable by physics and other natural sciences. However, due to ignorance, some people include scientifically explainable occurrences and behaviours among occult powers. For example, in Greek antiquity, when the Presocratic philosopher Thales of Miletus predicted an eclipse of the sun which indeed did occur in 585 B.C., ${ }^{7}$ 
some claimed he was able to do that because of occult powers which he possessed.

\section{African World View as Background to the Belief in Occult Powers}

The major background to Africans' belief in the influence of occult power stem from the way they perceive the world. For Africans, particularly black Africans, there are basically two worlds: the world in which we live and the world of the underworld, which is inhabited by spirits, ancestors and forces. These spirits and forces influence humans and could be appeased with sacrifices.

The traditional African world view is generally like a pyramid. At the apex is the Supreme Being; in the middle are the deities, gods and goddesses who are regarded as agents of the Supreme Being. At the lowest part of the pyramid are located human beings and other creatures. The deities are believed to be appeased through sacrifices and other religious observances. ${ }^{8}$

Because of the belief in the existence of a hierarchy of beings, Africans accept that some of the beings in the world are powerful. One can gain admittance into using the "supernatural" power given by them if one got initiated or is gifted.

A typical African believes that it is possible to get secret or occult power and knowledge which he may use negatively to influence his fellow human beings. This is on account of the African world view that:

...man is not alone in the universe; that there are some other creatures. When man gains admittance into the wisdom which these other creatures have, he is allowed to profit in a small degree from their hidden treasures of knowledge. ${ }^{9}$

Although some other cultures and traditions also accept the existence of beings other than man, in Africa this belief is often exaggerated or blown out of proportion. This is why there are more jujus (gods and 
goddesses) in Africa than in any other continent, even among highly educated people.

\section{Belief in the Occult and Paranormal among Africans}

Among Africans, particularly those inhabiting, southern, western, eastern and central areas of the continent, belief in occult and the paranormal is rampant.

In South Africa for example, people who were H.I.V. positive were told by medicine men/women that having sex with a virgin provided a cure for H.I.V/A.I.D.S. This false belief increased the number of people infected with the dreaded virus because the virgins who were innocent were contaminated and infected with the virus. The South African government reacted later to the trend and sought the license to produce antiretroviral drugs locally. That helped a lot!

In West Africa, belief in voodoo, mysterious powers and occultism has continued to spread. In Nigeria, for example, many police men who stand on the road with A-K 47 rifles also attach pieces of red clothes etc to their guns under the false belief that there are some armed robbers who cannot be killed by bullets because bullets from police riffles cannot pierce their bodies. They have "bullet-proof" bodies and they are said to have acquired such power through occultism.

The pages of the national Newspapers in Nigeria are often filled with stories of people who are said to have occult powers. This includes: witchcraft powers, sorcery, money-making jujus, ability to see and interact with the dead and the power to harm one's enemies from a distance, etc. Many people believe these stories. The influence of the media on paranormal and occult phenomena is much. The Vanguard Newspaper of Nigeria for example, reported sometime on its first page how the police were pursuing an armed robber and suddenly the robber changed into a goat. According to the story, the police arrested the goat and later charged it to court. They were convinced it was the robber that changed into a goat. The story reads:

It was a shocking sight yesterday as men of the Kwara State Police Command paraded a goat as an armed robbery suspect. The goat "suspect" is being detained over an alleged attempt to snatch a Mazda car. ${ }^{10}$ 
The police did not imagine that it was possible that the robber mixed up with the crowd present at the time of the robbery. They acted out of prior conviction and belief. If law enforcement agents could act in this manner, it shows the level at which belief in superstitious and occult powers operate in the Nigerian socio-political and socioeconomic spheres.

In Nigeria, in August 2008, the story of a local government chairman who set N250,000,000 (two hundred and fifty million) Naira ablaze made waves and attracted criticisms from everywhere. The chairman was asked to burn the money by a traditional medicine man as a way of casting spells on his enemies and subduing them so that they would have no power over him.

Apart from these cases, in the Central African Republic people are still being tried and sent to prison on accusation of witchcraft. Once a person is accused of such a "crime" by someone or the community, the accused is brought to traditional medicine man/woman who would prove the innocence or guilt of the accused through incantations and examination of the accused body. That is the only proof that is required. The judge in the court relies on the proof provided by the medicine man or woman without considering whether such is contrary to an objective understanding of justice and fair hearing. ${ }^{11}$ By such mundane practice, many innocent people have been sent to prison. This is possible because the Central African national constitution still has a provision that makes witchcraft a punishable offence. In Nigeria, it was in 1903 that the law that abolished witchcraft and juju was promulgated, while the law that proscribed unlawful societies (secret societies) was made in $1905 .{ }^{12}$

The instances of belief in occult powers enumerated above are only a few of the various beliefs in occult powers that pervade the multiethnic and pluralistic continent of Africa. This belief plays a major and important part in the psyche of many an African that even men and women in the academia who are supposed to have an objective assessment of the society are also enveloped in such pessimistic and ridiculous explanation of social phenomena, often without recourse to rational and critical assessment. 


\section{Mode of Acquisition of Occult Powers}

Occult power is normally got through two basic ways: either one is naturally gifted with such ability, or one acquires it by associating with a group from which one gets the power. Occult power could also be given to someone who has paid to acquire it. For example, there are people who pay to get charms and amulets which they believe will give them occult powers and protection.

Some philosophers have posited the existence other beings. In Greek antiquity, Anaxagoras for example, said there were bodies and beings other than humans. According to him, "beneath the heavenly bodies are certain bodies, invisible to us, that are carried around along with the sun and the moon."13 Even Aristotle in his discussion of the opinions of Anaxagoras and Democritus said that they believed in the existence of some heavenly bodies and objects. He discussed these heavenly bodies at length in his On Celestial Phenomena. $^{14}$

Among Christian theologians and philosophers the existence of other beings was not put in doubt. It is seen in St. Augustine for example, in his discussion on pagan deities, demons and Christian angels. ${ }^{15}$ In the Medieval era the angelic Doctor, St. Thomas Aquinas argued that there were immaterial beings. In the world therefore, there are beings that are quite powerful (positive or negative). People are able to get occult power from some of these other beings. The devil could also give someone an occult power, which will enable him (the possessor) to do things which naturally he would be incapable of. This kind of power is occult because it is not given to everybody, but to those who have pledged to abide by the rules and regulations given by him. Members of secret cults could get such power.

People who possess occult power can also make others acquire and use it. This is what happens when someone goes to a traditional medicine man to pay him in order to be given some occult power. Some claim to be able to make human beings "bullet-proof" in the sense that no gun fired at them will be able to pierce the body. Some have also claimed to have acquired "mysterious" powers from powerful medicine men. In Nigeria there are people who claim that they can take any quantity of alcohol drink without being drunk. Rather, other people who sit close by will get intoxicated, even 
though they have not taken any alcohol. I am still investigating into this issue, to find out whether it is true or false.

Some other occult powers are acquired by making of concoctions from herbs and other materials. This concoction is either smeared on some parts of the body or drunk, followed by some incantations. This is what happens in the case of witchcraft and sorcery where one gets the power by being a member of the cult and eating/drinking what he or she has been given. In the opinion of some self acclaimed witches, it might entail the drinking of human blood.

It is possible to get occult power through spirit possession. In this case a man or woman is possessed by a spirit which gives him/her the power to perform what normal human beings are not able to do. This is a rare occurrence. The person who is possessed serves as a medium and does what the spirit orders or demands. In Igbo culture of Nigeria, one could, through spirit possession get the power to know the herbs that are to be used to cure different illnesses. This kind of spirit is called Agwu or Agwu nsi. Such possessed people normally do become traditional healers. There is also temporary spirit possession by evil spirit. In this case the possessed exhibits behaviour that is queer and abnormal. Experts, particularly religious experts (and some faith healers) can cast the spirit out. There is however a difference between spirit mediumship and spirit possession (or demonic possession). While the former is often not harmful, as one acts as a messenger of the spirit, the latter brings about ill health. ${ }^{16}$

For the purpose of this paper, parapsychology, hypnosis, trance and religious faith healing are not regarded as occult powers. Thus, they are not regarded as modes of acquiring occult power.

\section{Examples of Occult of Powers}

There are several occult powers which some people claim to have. Some of them have been mentioned above. Some of the outstanding among the powers include:

1. Witchcraft: witches and wizards are said to be able to manipulate the forces to their advantage and can cause harm to their perceived enemies. The belief is found in 
many parts of Africa especially among people living in the coastal regions.

2. Pin-casting: having the invisible power to be able to cast out pins or pieces of iron which are supposed to be responsible for ill health.

3. Sorcery: sorcerers are presumed to have the power to cause misfortune, accidents or even to maim and kill people.

4. Necromancy: ability to conjure the dead, which some people claim to have. In Nigeria, for example, through mirror-viewing at Okija shrine (in Anambra state) and other places, people went to consult their death relatives and friends. In ninety-eight percent of the cases the aim of the visit or consultation was not achieved. Even some people who I sent to investigate and conjure their dead friend came back disappointed. They regarded the whole thing as a farce.

5. Money-making charms/jujus: there are people in Africa particularly in Nigeria who have committed murder because they were carrying out an instruction given them by a "specialist" who had the power of making them rich over night. In most of the cases the person concerned must kill his or her loved one in order to achieve his aim of being wealthy with little or no labour and effort. Astonishingly, from my research, those who claim to have this power of making others wealthy continue to live in near abject poverty. Their only source of income was from the clients and customers who came to their shrines. When I asked the question: you make this charm/juju for other people and you said it worked; why not make it for yourself, so that you would also become rich? The man replied that it would not work for him. It works only when he makes it for others.

\section{Can Occult Powers be Used to Solve African Problems?}

Many claimed occult powers in Africa and Nigeria are not real. It is not because they cannot be scientifically proved or investigated. No! There are things which are true, which science cannot investigate by the use of empirical methods. The fact of transubstantiation in 
Catholic theology, for example and many religious truths cannot be proved true or false by investigation or scientific evidence.

Rather, many claimed occult powers are not true because proper investigation into many of them, using the methods and criteria provided by the "holders" of such powers have not worked. Often claims are made, and when the investigation begins, the arguments begin to change. For example, a man claimed to have what in local language is called Odeshi, (literally meaning 'impenetrable' by bullets and knife). I asked him to allow me and my co-researchers to organize to have him shot at the leg. I even promised him some money. This man who was boasting of the power he had, surprisingly said since I had come to test his power that it would not work. According to him, it works only where there is real and apparent danger to his life. Since many claimed occult powers do not function as they claim, they cannot be used to solve issues and problems inherent in Africa.

One of the most widespread and known occult power in Africa and beyond is that of witchcraft. In Old Testament time it was inherent even in the culture and tradition of the Jews. In early Christian era it was regarded as pactum implicitum cum daemone (implicit pact with the demon) and was condemned.

The story of Saul and the witch of Endor in the Old Testament (1 Samuel 28:12-19) brings to the fore OT belief in the existence of such occult power. According to the Bible narrative, Saul had expelled all witches/wizards from Israel, but he disobeyed God in not killing the Amalekites as God had instructed him. God therefore decided not to communicate any longer with him. He was to be delivered into the hands of the Philistines. He called to God and $\mathrm{He}$ did not answer (as He used to). So, Saul disguised himself and went to Endor to consult one of the witches he (Saul) had banned from Israel. Saul asked the witch to bring up the spirit of Samuel, which she did. ${ }^{17}$ Samuel said to Saul, "why have you disturbed my rest by conjuring me up?" Saul then explained that he was distressed and wanted to know if he could win the war against the Philistines, but God gave know answer. Samuel told Saul that God was silent because He was annoyed with him and that he would be killed in the war. "What is more, Yahweh will deliver Israel and you too into the power of the Philistines. Tomorrow you and your sons will be with me;...." The whole thing happened as Samuel had predicted. The 
following day, Saul and his sons were slaughtered in the battlefield. So, the witch of Endor had an occult power which she used to conjure Samuel and helped Saul in his distress.

Witchcraft was also a problem in Europe. At a time, some popes had to issue instructions on how witches were to be treated. Even Canon Law had provision on how to extract information from witches.

The Catholic Church in Medieval Europe had teachings on witchcraft, like that of Thomas Aquinas (Summa Theologiae, 1 pars. q. 51, ad. 6), and the letters of Popes Gregory IX (Vox in Rama, 1233) and Innocent VIII (Summis Desiderantes Affectibus, 1484) which warned people of the danger of witchcraft. ${ }^{18}$

In the Medieval period, the Catholic Church saw witches and sorcerers as enemies of the faith and wanted to have them wiped out. With the Bull of Pope Innocent VIII persecution against them began. In Germany, two German Dominican monks "Heinrich Kraemer and Johann Sprenger were appointed as inquisitors, charged with carrying out the war against witchcraft in North Germany to a successful conclusion." "19 The joint work of Kraemer and Sprenger entitled Malleus Maleficarum became at that time a reference book on witchcraft and how to deal with it. What followed was decades of inquisition during which condemned witches were burnt at stake. Witchcraft never helped Europe to progress. Although development, industrialization and enlightenment have helped Europe to overcome and overgrow the belief and dependence on witchcraft, in Africa, the trend is different. Many still hold on to it.

In spite of witchcraft confessions and people claiming to belong to the group, objectively speaking, in reality and factually it is difficult to establish witchcraft existence in the same way it is difficult to totally deny its nonexistence. However, from the nature of operation of so called witch covens, witchcraft cannot be used to solve African problems because it is basically negative and perceived enemies and opponents are attacked. Witches are people who have no morality. What they do is normally hidden. Some of the stories about witches and their activities are over exaggerated. 
Witchcraft cannot be used to influence economic and political problems in Africa. Even in South Africa where there was apartheid and official racial discrimination for decades and in countries like Nigeria and Congo where the politicians are corrupt, witchcraft has no solution to offer. It does not have the power it claims to have. Psychologically, it is possible that due to the image which has been imprinted on the psyche, a person could be said to have been influenced by witchcraft.

Apart from witchcraft there is the problem of pin-casting. Occult power said to have been possessed by those who practice pincasting is a farce. They play on the psyche of their clients who are often very gullible on account of the illness from which they are suffering. They are therefore ready to do whatever they are told. When they are told that some pins have been removed from their bodies, they believe it to be true.

Sorcery operates in a similar way as witchcraft. This, also, does not offer any hope of its being used to solve African problems. Why can't sorcerers use their acclaimed power to impact positively on the stock market, or use that power to "force" political leaders to open up more factories to employ more people in order to reduce unemployment. This, too, is not possible. Some cases of sorcery have been discovered to be psychological disorder, which impinge on the mental health of the so called sorcerer.

Necromancy is another occult power which some people in Africa claim to have. My research revealed that this is a rare occurrence. I could not get any necromancer who was able to conjure the spirit of a dead person in order to get relevant information. Those necromancers who claim to conjure the dead by the use of mirrors and other devices, deceive their clients, whom they often tell to do what is almost impossible. If necromancy were to work, it would have been a veritable tool in solving cases in Africa, especially cases that have to do with will and inheritance. Many Africans do not write wills and when they die, their families are thrown into confusion and the struggle for properties begins to tear the family apart. Again, necromancy would have been very useful in solving unresolved murder cases. But we know that there are many murder cases in Africa and the world that are not yet resolved. Often, a scientific way of resolving them is to carry out a DNA test. This is costly and demands time. 
The dwindling of world economy, high unemployment rate and increasing poverty ratio among the peoples of the world have made some Africans to look for an easier way of making money. Some engage in illicit businesses, like the traffic in narcotics and the sale of inferior and low quality materials, while others resort to making of charms and amulets as ways of getting rich quick. Some believe that these charms would help them to get rich overnight. My research reveals that the traditional medicine men who claim to have the power of making people rich do not really have such power. Even people who join secret societies and clubs do not become wealthy on account of the occult power which they have "acquired", rather the association with highly connected and wealthy people helps them to get money for their businesses and open to them other avenues to financial growth. If money-making jujus and charms work the way their proponents claim, why couldn't they be used to make so much money as to be able to wipe away poverty among Africans and peoples of the world? Africans could have used it repay the debts they owe international communities and financial institutions. Many Africans are very poor and earn less than \$2 per day. The hope of making money quickly makes some Africans lazy. Instead of working very hard, some waste their time and at the end go to make charms that do not work. When they discover the charms have not given them what they hoped for, they begin to suffer from depression and high blood pressure.

\section{Conclusion: The Way Forward}

Man is a material as well as a spiritual and metaphysical being. In his materiality he seeks to satisfy his needs which basically include food, shelter and basic comfort. The quest to satisfy these needs leads him into doing various things to better his conditions and make himself happy.

On the other hand, as a spiritual/metaphysical being man believes in the existence of superior or supernatural beings and powers. Often he seeks to have a share in the superior powers, powers which are beyond his normal capability. So, he seeks to obtain powers which are occult. This is not given to all but only to a few who are either gifted with such or who try to get it through other means in order to use it for their own advantage. 
There are very few people in the world who can boast of having real occult power. Often the possessors shroud this in secrecy and mystify it. Many others claim to have occult power because it makes them "superior" to the rest. Thus, the issue of occult power is exaggerated among Africans especially among Nigerians. Very many people are therefore deceived into believing that occult power is rampant. As a result, even highly educated and highly placed people believe in this, to the detriment of societal life and progress. Today, it is not easy to clear the minds of the people and their strong belief in occult power and its acclaimed efficacy.

One of the ways of helping to solve this problem is to educate the people properly that belief in a wide spread occult power is not in order. Africans should be taught to know that there is a difference between the natural powers which herbs and substances have, (which could be explained scientifically) and the exaggerated, mystified power which traditional medicine men and others take to be as a result of occult power. This education that is required should involve the study of philosophy which is a discipline that raises critical questions on issues, and anthropology, which studies peoples and cultures. People will then be able to look at the issue of occult powers more critically. If the ability to have and manipulate occult powers is very wide spread and efficacious, why have Africans not used them to solve their socio-political and socio-economic problems? The introduction of philosophy and anthropology at the primary and secondary institutions will be a right step in the right direction towards solving this problem that has misdirected some Africans; even academics, law enforcements agents, politicians as well as men and women, young and old.

\section{Notes and References}

** This paper is based on a research on the paranormal and the occult sponsored by the Volkswagen Foundation of Germany. I am grateful to the foundation for the opportunity.

${ }^{1}$ Chambers $20^{\text {th }}$ Century Dictionary, edited by E. M. Kirkpatrick.

Edinburgh: W \& R Chambers Ltd., 1983, p. 874.

${ }^{2}$ Loc. cit. 
${ }^{3}$ J. Obi Oguejiofor, "Occult Powers and Socio-Economic Dynamic in Nigeria" in Bigard Theological Studies, July - December 2006, Vol. 26 No. 2, p. 11.

${ }^{4}$ Oguejiofor argues that "both religious and occult beliefs are not always amenable to the usual rule of logic, and their claims are often not verifiable by empirical causal explanations." Loc. cit. In religion, the adherent may pray for the intervention of the divine in normal human affairs, while in occultism, the adherent commands the invisible occult forces and wants to use them to his own advantage and often to the detriment of others and the society. "In most cases, possession of occult power is linked with the ability to do evil." Loc. cit.

${ }^{5}$ Aloysius C. Obiwulu, "Influence of the Paranormal and the Occult on the Life of Nigerians" in The Paranormal, the Occult and Society, edited by Aloysius C . Obiwulu. Enugu: Delta Publications, 2008, p. 9.

${ }^{6}$ William Lane Craig, "Creation, Providence and Miracles," in Philosophy of Religion, edited by Brian Davies. London: Cassell Publishers, 1998, p.152.

${ }^{7}$ Thales came from the Greek Island of Miletus. He was regarded as one of the seven sages of Greece because of his extraordinary wisdom. In his days, philosophy was to some extent mixed up with mythology and religion. Thales combined philosophy with science, cosmology and practical wisdom. "He is stated on good authority to have predicted an eclipse of the sun which the calculations of modern astronomy show to have occurred in the year 585 B.C." See Alfred William Benn, Early Greek Philosophy, London: Archibald Constable and Co. Ltd., 1908, pp. 15-16.

${ }^{8}$ Aloysius Obiwulu, "The Impact of Slavery on the Demographic and Economic Growth of Africa" in J. Obi Oguejiofor (ed.), Philosophy, Ideology and Civil Society. Owerri: Living Flames Resources, 2009, p.360.

9 Aloysius Obiwulu, "Influence of the Paranormal and the Occult on the Life of Nigerians" in Aloysius Obiwulu (editor), The Paranormal, the Occult and Society. Enugu: Delta Publications Ltd., 2008, pp. 10-11.

10 "Police Parade Goat as Robbery Suspect" in Vangaurd Newspaper, Vol. 25, Number 60767, January 23, 2009, pp. 1 and 5. The photograph of the goat was published on page 5 of the Newspaper. Other Nigerian Dailies also published the same story.

${ }^{11}$ The American television network, CNN reported on April 27, 2009 that in Bagandou, a town in Central African Republic, witchcraft accusation is still rampant in the area. Those accused range from young people to very old men and women. We know it is very difficult to prove beyond reasonable doubt that someone is a witch or wizard. In Bagandou some 
people had been imprisoned because they were found guilty of "eating" the soul of people.

${ }^{12}$ B. Obinna Okere regarded these laws as obnoxious. They were aspects of Nigerian native law and custom. They have been abrogated by civil legislation. See B. Obinna Okere, "Nigerian Customary Law and the Received English Law: Confrontation and Harmonisation" in Religion and African Culture, edited by Elochukwu E. Uzukwu. Enugu, Snaap. No date of publication given, p. 31 .

13 The First Philosophers: The Presocratics and the Sophists, a new translation by Robin Waterfield. Oxford: Oxford University Press, 2000, p. 128, paragraph $\mathrm{T} 9$

${ }^{14}$ For more details see Aristotle, On Celestial Phenomena 345a25-9, translated by Bekker.

${ }^{15}$ Confer: St. Augustine, The City of God, translated by Gerald G. Walsh, Demetrius B. Zema et al. New York: Image Books, 1958, see Book IX, chapter 1 .

${ }^{16}$ For more details, see Spirit Mediumship and Society in Africa, edited by John Beattie and John Middleton, foreword by Raymond Firth. New York: Africana Publishing Corporation, 1969, p. ix. This work was quoted by Raymond Arazu, Man Know Thyself. (Discovering the Master Plan by Knowing which Everything else is Known). Enugu: Snaap Press Ltd., 2003, pp. 58-59.

${ }^{17}$ See 1 Samuel 28: 12-19). According to the Bible, "The woman then saw Samuel and giving a great cry, she said to Saul, "why have you deceived me? You are Saul!” The king said, 'do not be afraid! What do you see?' The woman replied to Saul, 'I see a ghost rising from the earth.' 'What is he like? he asked. She answered, 'he is an old man coming up; he is wrapped in a cloak.' Saul then knew that it was Samuel and bowing to the ground, prostrated himself."

${ }_{18}$ Aloysius Obiwulu, "Influence of the Paranormal and the Occult on the Life of Nigerians" in Aloysius Obiwulu (editor), The Paranormal, the Occult and Society, op. cit., p. 15.

${ }^{19}$ Raymond Arazu, Man Know Thyself, op. cit., p.78. See also George Ryley Scott, History of Torture. London: Sphere Books Ltd., 1971, cf. 95ff. In spite of what the Catholic Church did in Medieval Europe, it was only in 1951 that the Witch Act was totally abrogated in Britain. 